\title{
National planning in South Africa: a critical review
}

\author{
J. E. Drewes \& M. van Aswegen \\ North-West University, Potchefstroom Campus, South Africa
}

\begin{abstract}
According to the European Regional/Spatial Planning Charter (1983), "Regional/spatial planning gives geographical expression to the economic, social, cultural and ecological policies of society. It is at the same time a scientific discipline, an administrative technique and a policy developed as an interdisciplinary and comprehensive approach directed towards a balanced regional development and the physical organisation of space according to an overall strategy”. It is against this background that this study reviews past spatial planning policy and how it gave "geographical expression" to economic, social and cultural policies in South Africa

This paper aims to provide a critical and objective perspective on national spatial planning since the inception of the concept in South Africa in the 1970s till the most recent directive in 2012. The paper will discuss the understanding of national planning in South Africa in terms of the economic approach and spatial implementation of each plan.

It is argued in this paper that over the past three decades the national space has been left open for interpretation in terms of economic growth and development, which has led to a lack of execution of the well-intentioned spatial guiding documents from the various levels of government. It could be interpreted that spatial planning in South Africa has come full circle since the 1970 `s, being once again politically driven, this time by social policy, and not economic policy. The paper proposes that national spatial planning should, once again, start to focus on giving clear guidance on how, where and when the magnitude of social and economic goals should be reached.
\end{abstract}

Keywords: national planning, spatial planning, regional planning; South Africa planning history. 


\section{Background}

During the most recent history of national spatial planning in South Africa there has been a definite drive towards economic growth, which overshadowed all other developmental goals. During the 1970s till 1991 development was primarily driven by industrial development in specific areas earmarked for concentration. The focus was on extracting and maximizing the potential of the vast natural resource pool of the country. The reasoning behind this specific era`s development was, however, dominated by the political ideology of separate development and centred around these principles.

Throughout the history and evolution of spatial planning and policy in South Africa, three main perspectives are evident. In the latter part of the previous millennium, economic growth was seen as the all-encompassing goal in national development. National policy, although founded on political ideology, was based primarily on industrial development in areas earmarked for concentration. An emphasis shift occurred in the early 1990s towards a balanced policy approach, whereby a participative or people-centred approach replaced the previous 'fordist' approach to development. In the mid-1990s, the principles of resource management or environmental sustainability were also accepted as being part of the spatial planning and policy formulation process. The latter two approaches to development are clearly process-driven, i.e. the integration of principles, community participation and environmental sustainability in spatial planning, are of utmost importance. In contrast, the end result of economic growth and separate development was the main goal in the previous regime`s approach to spatial policy formulation up to the 1990s in South Africa. In the new millennium the "geographical expression" of spatial planning is again focused on social and political issues.

It is the aim of this paper to give insight in the evolutionary development of national development policy is South Africa. This paper will analyse the relevant policies influencing the development of the national space as implemented over the past five decades. South Africa is quite a unique example because of its policy of separate development instigated in 1948 by the Nationalist Party, up to the present socialist-oriented democratic government.

\section{Chronology}

The spatial planning milieu in South Africa has changed drastically over the past 40 odd years. From the first spatial policy initiative, the National Physical Development Plan (1975) radical changes have occurred in the approach to national planning. Since 1975, South Africa has seen the Good Hope Plan (1981), the Regional Industrial Development Programme (1991), Reconstruction and Development Plan (1994), Urban and Rural Development Frameworks (1997), SMME development (1996), Spatial Development Initiatives and Industrial Development Zones (1999), and two National Spatial Development Perspectives (2002 and 2006). The most recent spatial planning directive in South Africa is the National Development Plan (2012), which has a diverse 
approach with political, social and economic goals. During this time national planning policy and directives have moved through balanced and unbalanced growth approaches, from a top-down approach with rigid area-specific directives to a bottom-up more adaptable, socially-oriented and interpretation-based approach in recent years. The main pillars of spatial policy in South Africa have always been the development and deconcentration of the industrial sector. This remained the focus of this type of policy until the early 1990s, when smaller industries and the services sector were also added to national policy. South Africa`s spatial policy has evolved from a policy dominated by political objectives in the 1960s, to a policy supposedly based only on economic principles of a free-market system; from one of strong government intervention to one of little intervention.

\subsection{National physical planning: 1975 -1991}

In the National Physical Development Plan (NPDP) (1975) the Decentralization Board identified growth points through a top-down approach (SA [2]). This plan contained various planning instruments aimed at the arrangement of the physical development according to specific development and political ideals. Fair [3] divided the report into two parts. First, a growth centre strategy was proposed in order to obtain more balanced spatial poles. Secondly, a framework which divided the country into 38 planning regions was proposed. The NPDP could therefore be regarded as the overall framework through which the decentralization policy was implemented (Bos [4]). Many of the officially proclaimed industrial points were located in sparsely populated areas as well as in the peripheral economic space of the country. However, numerous studies have indicated that the development of sparsely populated areas should take place in stages, emanating from a strong economic core. Efforts to 'plant' a growth point away from a national or regional economic core have proven fruitless (Stern [5]; Bloch [6]). The proposed development initiatives in both instances (growth poles and growth points) primarily aimed to create work opportunities. Industrial development, however, is stimulated in the growth points by means of extended infrastructural development (Bos [4]). Therefore, the NPDP aimed to focus national planning in a spatially unbalanced manner, as well as targeting economically unbalanced development (Rosenstein-Rodan [7]) through its focus on industrial development.

The beginning of the eighties witnessed a marginal shift from the extreme practices of White paternalism of the past (Geyer [8]) with the Good Hope Plan (GHP). After deliberations between the government and private sector, the GHP was announced in 1981. The plan contained a number of industrial development guidelines, a framework through which the Government, in a top-down approach, intended to implement its new industrial decentralization policy. Altogether, a total number of 47 'industrial development points' and 11 'deconcentration points' were designated to be developed simultaneously (SA [9]). 'Deconcentration points' were identified adjacent to metropolitan regions to relieve pressures of industrial concentration in these areas (SA [9]). Similar to the NPDP, almost all of these 'deconcentration points', as well as the 
overwhelming majority of the 'industrial development points' were located within peripheral areas. Apart from their impractical locations from an economic point of view, too many of these points had been identified, incentives has been spread over too many geographical areas and the dispersed pattern of too many growth points also raised doubts as to whether such a strategy could ever be implemented successfully (Stern [5]). This plan could, therefore, be summarized as having an economically unbalanced as well as a spatially unbalanced approach and intent.

From the first two national plans it is evident that decentralization policy, implicating a certain growth centre strategy, played a major part in development thinking in South Africa since its inception in peripheral region development in the 1950s. A major shift in decentralization policy occurred in 1991 with the implementation of a new, apolitical, Regional Industrial Development Programme (RIDP [10]), based on a uniform development approach (Rosenstein-Rodan [7], Baldwin [11], Hirschman [12]). Proposals by the Development Bank of Southern Africa were made regarding the nature of a new profit/output-based incentive scheme, its level of incentives, and the specific spatial application of the incentive scheme. Because of the supposedly limited achievement of self-sustaining growth at industrial development points and the assumption of the inability of the growth centre to support the above-mentioned principles (SA [13]), the RIDP was proposed and implemented in 1991 (SA [10]). According to Bell [14] the 1991 RIDP represented a fundamental split from the past. Its professed aim is mainly economic, in particular, promotion of 'the self-sustaining economic growth and development of integrated economy' (POE [15]). In view of the alleged inability of the previous approach to give effect to the accepted principles and a declared policy of a greater democratisation of the economic processes, a spatially uniform approach (Friedmann [16]) was formulated based on the above-mentioned guidelines. Again, however, two implicit assumptions were repeated, i.e. that metropolitan areas are over concentrated and that the promotion of secondary industry is the most effective means of achieving development (Luiz and van der Waal [17]). A distinction was made between three levels of incentives according to the development status of an area. Accordingly, entrepreneurs settling in the major metro`s (Gauteng complex and the Durban core area) received no incentive for industrial development, while new developers in the emerging metro`s (Cape Peninsula, Durban-Pinetown-Pietermaritzburg, greater Durban functional region and the area surrounding the Gauteng region) received 60 per cent of the calculated establishment allowance (100 per cent after two years). The rest of the South African spatial area rendered the new industrial developer eligible for 100 per cent of the established allowance for the five year period (SA [10]). The primary advantage of this RIDP, namely locational freedom, allowed the new industrial developer to pick a site of his choice anywhere in the country - save in metropolitan regions - and receive 100 per cent establishment incentives (Ligthelm and Wilsenach [18]). The second primary advantage of the RIDP was its 'political correctness' (Black and Roux [19]). This issue was emphasised by Luiz and van der Waal [17], who indicated that the government tried to appease 
all interest groups by making the incentive nationally applicable and avoided making tough decisions. In fact, except for the 'restrictions on new development' in metropolitan regions, the government essentially implemented a laissez-faire approach (Drewes and Bos [20]).

\subsection{Sectoral national planning initiatives: 1994 - 2010}

After coming into power in 1994, the African National Congress (ANC) undertook to ensure equal access in all sectors by creating and implementing the Reconstruction and Development Programme (RDP) (1994). The RDP was the first economic/spatial programme after the apartheid era and is regarded as a bridge between the apartheid and post-apartheid era (ANC [21]). From this point the approach of national planning changed drastically. The RDP was an integrated socio-economic policy framework that aimed to "mobilize all the people and our country's resources towards the final eradication of apartheid and the building of a democratic, non-racial and non-sexist future” (ANC [21]). The RDP`s integrated approach to developing and implementing policy was the first of its kind in the political history of South Africa, which brought with it a whole new paradigm shift which conveyed new challenges. The six basic principles the RDP was founded on was (ANC [21]): (i) integration (ii) people- driven process (iii) peace and security. (iv) build the nation (v) link reconstruction and development (vi) democratization. To improve and accelerate the development linked with the RDP the Development Facilitation Act (DFA) was created. This was a fast-track approach to development in order to have more effective decision-making and delivering (SA [22]). The DFA bypassed all apartheid legislation and initiated development planning through land development objectives. Accordingly the RDP was spatially balanced, and in theory everybody had equal access to economic activities. The RDP was a programme and did, however, not have a physical spatial plan indicating where development should take place.

One of the first attempts since the 1980`s at national spatial planning was initiated by the RDP Office in the form of the National Spatial Development Framework (NSDF) in 1995. According to Oranje [23] this framework was an 'outcome of concerns about uncoordinated expenditure and a lack of shared standards in infrastructure investment'. It was foreseen that the framework would commence with the mapping of the whole country through GIS in order to stimulate dialogue on future investment localities. The 'framework', however, never got past the stage of initial mapping and died a still death. The NSDF came to abrupt end with the closure of the RDP offices in 1996 (Oranje [23]).

Following the above approach, the Growth Employment and Redistribution (GEAR) strategy in 1996 announced an economic reform programme directed towards: (i) competitive fast-growing economy; (ii) redistribution of income opportunities; (iii) capable society; and (iv) safe environments and productive workplaces (SA [24]). These principles went on to form the macro-economic framework within which the Rural Development Framework (1997) and Urban Development Framework (1997) was established. Robbins [25] confirms that GEAR 'limited itself to focusing on traditional macro-economic policy 
instruments and did little to explore the ramifications of such national choices'. The GEAR strategy was regarded as being spatially and economically balanced, and being driven from the top-down, although being informed by the people`s needs. The GEAR strategy did not emanate a specific spatial approach linked to locations or using planning mechanisms and is regarded as an economic strategy, rather than a spatial one.

A key document providing the leading perspective on rural development is the Rural Development Framework (RDF) of 1997 (SA [26]), which was borne out of the relative inactive RDP. It highlights the RDP's role as embodying the commitment of government to the eradication of poverty in a rapidly growing economy and in the context of an open, peaceful and democratic society. The RDF was established in order to provide a counterbalance to the Urban Development Framework (UDF) (SA [27]). Therefore, this framework can be classified as a spatially unbalanced framework with its focus on rural areas and aiming to provide a more balanced rural economy. Rural South Africa came with its own unique set of difficulties, referring to high poverty levels, the multisectoral nature of rural development, marginalised economies and in some instances having a high environmental sensitivity (SA [26]). The Framework acknowledged that to balance out the rural economic space it had to improve and develop the relevant institutional capacity and infrastructure.

The Urban Development Framework (UDF) of 1997 was specifically aimed at developing urban nodes (SA [27]). The Framework had a vision of spatially and economically integrated centres, providing the inhabitants economic and social opportunities, good housing and infrastructure in a participative fashion. The UDF accordingly, further strived towards environmental sustainability with vibrant urban governance, and an integrated approach to various land uses. It mainly has four key programs, (i) integrating spatially segregated and sprawling cities; (ii) improving housing and infrastructure; (iii) promoting urban economic development; and (iv) creating institutions for ensuring delivery of basic services and support. Urbanizing centres created many challenges and realities, i.e. a large and growing urban population, inequality and poverty, financial pressure on municipalities, a vibrant and dynamic urban society, and immense economic and financial potential for urban revitalization. The UDF was regarded as a framework aiming to provide a balanced urban economy, while being spatially unbalanced, focussing only on urban South Africa.

The policy of Spatial Development Initiatives (SDIs) was accepted in 1996 to supposedly address fragmented development patterns, and to promote equity, integration and efficiency (SA [28]). The SDI approach was developed based on the lessons learnt on regional development in the European Community (Oranje [23]). Robbins [25] affirms that the launch of the SDI 'heralded something of a shift in thinking towards some measure of recognition of the benefit of more spatially differentiated national policies and programmes'. Developmental regions, axis's and projects identified by their inherent under-utilised economic potential, aimed at sustainable employment creation, by identifying and facilitating new investment opportunities. Private and public investment were stimulated through infrastructure, manufacturing, mining, small business 
(SMME), tourism, agriculture, housing and the provision of water to achieve the advantages of agglomeration (Wiese [29]). With the establishment of the SDIs, the approach reverted back to the principles of earlier policies of 1960 and 1982. The aim was, once again, to create employment near people's homes, especially in the rural areas, to ensure balanced development - with all the associated linkage benefits. (Drewes and Kleynhans [30]) SDI policies were outward orientated, aimed at the supply and demand of commodities of which South Africa was said to have a comparative advantage. Businesses, with large backward and forward linkages, were encouraged in order for more industries to develop in a centripetal action and create more employment (Drewes and Kleynhans [30]). The identification of possible clusters also played an important role in the development of SDIs. The former government was accused of establishing industries in the homelands without supplying the necessary infrastructure, however, SDI projects were identified wherever potential exists and the authorities ensure that necessary infrastructure are provided and developed, making this a spatially and economically unbalanced initiative.

The Integrated Sustainable Rural Development Strategy`s (ISRDS) main thrust was to ensure that government departments had a common platform and approach for implementing rural development strategies and programs (2001). It also put emphasis on the relationship between rural and urban economies, and furthermore affirmed that a sustainable economic growth can be achieved if it is premised on linking exploitation of rural assets and redistribution. It stated that agriculture, for example, has strong forward and backward linkages into the rest of the economy, and together with SMME and Tourism had the capacity to create labour intensive jobs as well as in related industries, giving rise to income distribution in the national economy (SA [31]). The objective of the ISRDS was to improve the quality of life of rural citizens through alleviating poverty and providing sustainable livelihoods. It outlined the following key policy issues, i.e. (i) obstacles inhibiting rural development; (ii) employment creation and economic development; (iii) building rural infrastructure; (iv) prioritise the needs of the vulnerable groups; and (v) building local government capacity. As part of the ISRDS, the President identified 13 Nodal Development Points throughout the country. They served as pilot projects to fast-track rural development in selected areas. The ISRDS was a spatially as well as economically unbalanced strategy.

On-going concerns about the spatial impact of apartheid on existing towns and cities led to the formulation of the National Spatial Development Perspective (NSDP), in 2003 (SA [32]) and again in 2006 (SA [33]), to provide guidance in the spatial planning and provision of infrastructure. 'In terms of the Cabinet's approval of the first NSDP (2003) it was not only meant to be an indicative tool for all spheres of government to guide development and expenditure, but also acted as a platform for discussion and debate regarding national planning (Oranje [23]). According to the NSDP, infrastructure investment should primarily support localities that will become major growth nodes in South Africa and the SADC region to create regional gateways to the global economy. According to Hughes [34] the NSDP placed 'far greater emphasis on people than places' as a direct result of the spatially distorted legacy of apartheid, and plays an important 
social role to uplift the socially exclude and equalize all people. The NSDP principles facilitated structured and rigorous analysis that enabled comparison between places and sectors, and assisted all spheres of government in weighing up trade-offs, making clear choices and maximising the impact of scarce state funds. The NSDP categorises the municipalities of South-Africa according to their economic potential and also their human need. According to Oranje [23] an 'unease' regarding the second version of the NSDP (2006) arose due to it being perceived as having a more unbalanced approach. Oranje states that the NSDP is often referred to as being 'ant-rural', stimulating growth only in urban areas of high potential and lower need, as opposed to rural areas mostly characterised by low potential and high need. The NSDP was the first policy/perspective to focus on the whole space economy since the GHP of 1981. The NSDP envisioned a spatially balanced South Africa by providing unbalanced economic support to specific areas of need and potential. However, it must be noted that the NSDP didn't include any physical plan and compliance to the framework was voluntary.

In 2010 the New Growth Path (NGP) set a target of creating five million jobs over the next decade, through reducing unnecessary red-tape, improving competition in the economy and stepping up skill development (SA [35]). The NGP regarded investments in five key physical and social infrastructure areas energy, transport, communication, water and housing - as being a critical factor in growing the economy. The government believes that high levels of public investment in these five areas would create the required jobs in construction, operation and maintenance of infrastructure. The target of the NGP is to reduce unemployment which can only be achieved if the social partners and government work together to address key structural challenges in the economy. As a first step, government would have focused on unlocking the employment potential in six key sectors and activities, i.e. infrastructure, agriculture, mining, green economy and manufacturing. The macro-economic approach entailed more active monetary policy interventions to achieve growth and jobs targets, inter alia through a more competitive exchange rate and a lower cost of capital, with a more restrained fiscal stance and reprioritisation of public spending to ensure sustainability over time. The micro-economic approach involved targeted measures to support jobs and competitiveness, which in turn should have made the macro-economic strategy sustainable and viable. This approach is regarded as aiming for balanced spatial and economic development. It could be argued that national planning in South Africa returned to its origins of the 1990s, being once again politically driven, this time by social policy, and not economic policy.

\subsection{A new direction in National Development Planning: 2012}

In 2012 a need was identified for the coordinated and focused implementation of a plan on national level to eradicate poverty and exclusion in South Africa, from which the National Development Plan (NDP) (2012) was borne (SA [36]). The main argument of the National Planning Commission (NPC) regarding the need for a national plan referred to the poverty cycle and exclusion of the majority of people from opportunities for further education. The report outlined nine major 
challenges that South Africa faces, which fall under two major focus areas namely the need to eliminate poverty and reduce inequality. The following issues has been identified as obstacles inhibiting transformation, i.e. (i) Poor education outcomes (ii) High unemployment (iii) High disease burden (iv) A divided society (v) Public services that often fail the poor (vi) Parts of the country where people are locked into poverty (vii) Crumbling infrastructure (viii) inefficient use of natural resources (ix) Corruption. The NDP aims at creating a virtuous cycle whereby opportunities are expanded, leading to building the capabilities of the nation, resulting in a reduction in poverty and community development, ultimately giving rise to higher living standards and completing the cycle where opportunities for the next generation is expanded. The intended result of the NDP can be summarised as follows: (i) Creating jobs and livelihoods; (ii) Expanding infrastructure; (iii) Transitioning to a low-carbon economy; (iv) Transforming urban and rural spaces; (v) Improving education and training; (vi) Providing quality healthcare; (vii) Building a capable state; (viii) Fighting corruption and enhancing accountability; (ix) Transforming society and uniting the nation. The NDP supposedly recognizes the need for leadership on all levels (from national to community). At the core thereof lies the dire need for growth and development, supported by strong leadership, capable state and sacrifice on all levels of participation, this plan aims to gain national consensus and social cohesion.

From a physical planning perspective, the NDP also proposes the development of a national spatial framework (NSF) involving government, business and civil society to create a collective vision. This hasn 't been done yet, but the NSF will target a number of spatial areas, of which the following are mentioned: national competitiveness corridor; nodes of competitiveness; rural restructuring zones; resource-critical regions; transnational development corridors; special intervention areas. This will be first official national planning framework, giving specific and definite geographic expression to the use of financial resources to influence the space-economy of South Africa since the Good Hope Plan of 1981.

\section{Concluding remarks}

National planning in South Africa has left somewhat of a sour taste in the mouths of politicians and the public alike, due to its history of enforcing separate development through spatial planning tools. South Africa seems to have been planning on a first-world level (social goals) instead of on a third-world level (focusing on economic growth and infrastructure development). It is known that social goals are not attainable without true economic growth. Is economic growth then obtainable if "geographic expression" is not given through national spatial planning? As so eloquently put by Tony Blair "It is not an arrogant government that chooses priorities, it's an irresponsible government that fails to choose.”

It is the argument of this paper that over the past three decades the national space has been left open for interpretation in terms of economic growth and 
development, which has led to a lack of execution of the well-intentioned spatial guiding documents from the various levels of government. The expertise does not exist on the provincial and local municipal levels to give expression and influence economic development with the wide range of social goals given in more recent spatial planning guidelines. Only in the most recent initiative, the National Development Plan (2012) has the concept of geographical-ordering and influencing the physical development of the country by means of spatial planning tools become acceptable and an approachable subject. By means of the National Spatial Framework (as proposed in the National Development Plan) planning in South Africa will probably be able to break through the past barriers and formally plan for growth and development in an organized and recognized manner. It can only be hoped that this time a national level plan will be able to guide and assist local and provincial authorities more clearly and specifically on the physical translation and manifestation of social goals. The new National Spatial Framework should aim to find the golden path between being too rigid and autocratic and being a wish-list of unattainable desires, leaving the spaceeconomy open for interpretation of unattainable social goals. In his most recent State of the Nation Address (February 2012) President Jacob Zuma identified five major geographically-focussed programmes, as well as projects focusing on health and basic education infrastructure, information and communication technologies and regional integration, covering the national space. These projects, if successfully implemented, should be the launch of a new era in national spatial planning for South Africa.

\section{References}

[1] Council of Europe, European Regional/Spatial Planning Charter (Torremolinos Charter). Strasburg: CoE, 1983.

[2] South Africa. Department of Planning and the Environment, National physical development plan, Pretoria: Government Printer, 1975.

[3] Fair, T.J.D, The National Physical Development Plan (NPDP): a summary and review, South African geographical journal, 57(2), pp. 126-133, 1975.

[4] Bos, D.J, Ruimtelike ekonomiese implikasies van nywerheidsontwikkeling. Potchefstroom PU for CHE. (Dissertation - M. Art. et Scien.), 1987.

[5] Stern, E., Developing the inter-metropolitan periphery, Town and regional planning, 20, pp. 4-10, Sep, 1985.

[6] Bloch, R., Post-war regional planning: theory and record, The South African Journal of Economics, 58(2), pp. 139-156, Jun, 1989.

[7] Rosenstein-Rodan, P. Problems of industrialisation of Eastern and Southeastern Europe. Economic journal, LIII, pp. 202-211, 1943.

[8] Geyer, H.S, Industrial development policy in South Africa - the past, present and future, World development, 17, pp. 379-396, 1989.

[9] South Africa, Department of Foreign Affairs, Good Hope Plan, Pretoria: Government Printer, 1981. SA see South Africa. 
[10] South Africa, Board for Regional Industrial Development, Regional Industrial Development Programme (RIDP), Incentive scheme introduced on 1 May 1991, Midrand: DBSA, 1992.

[11] Baldwin, R.E, Economic development and growth. New York: Wiley. 150 p, 1972.

[12] Hirschman, A.O, The strategy of economic development, New York: Norton, 1958.

[13] South Africa, Office for Regional Development, National Regional Development Programme: general overview, Pretoria: Government Printer, 1991.

[14] Bell, T. South African Regional Industrial Development Policy: Critical issues, Transformation, 32, pp. 1-30, 1997.

[15] Panel of Experts, Evaluation of the regional industrial development program as an element of the regional development policy in South Africa, Midrand: Development Bank of Southern Africa, 1989.

[16] Friedmann, J, Regional policy: a case study of Venezuela. Cambridge, MA: M.I.T. Press, 279 p, 1966.

[17] Luiz, J.M. and van der Waal, C.S, Re-evaluating South Africa's Regional Industrial Development Programme: case studies from Brits and Nkowankowa, Urban forum, 8(1), pp. 61-79, 1997.

[18] Ligthelm, A.A. and Wilsenach, A, A preliminary evaluation of the new RIDP and its impact on regional development in South Africa, Development Southern Africa, 10(3), pp. 361-381, Aug, 1993.

[19] Black, P. and Roux, A, The spatial dimension of regional policy selectivity versus uniformity, Development Southern Africa, 8(4), pp. 445-488, Nov, 1991.

[20] Drewes, J.E. and Bos, D.J, The Regional Industrial Development Programme: an evaluation, South African journal of economics, 63(2), pp. 247-270, 1995.

[21] African National Congress. The reconstruction and development programme, Johannesburg: Umanyano, 1994.

[22] South Africa, Development Facilitation Act, no. 67 of 1995. Pretoria: Government Printer, 1995.

[23] Oranje, M, Post-apartheid national spatial development planning in South Africa - a brief history, European Spatial Research and Policy 17(2), pp. 55-70, 2010.

[24] South Africa, Department of Finance, Growth, Employment and Redistribution Strategy, 1996.

[25] Robbins, G, Reflecting on South Africa's post-apartheid experience with spatially informed economic development programmes, Think piece for TIPS Forum October, 2008.

[26] South Africa, Department of Land Affairs, Rural Development Framework, Pretoria: Government Printer, 1997.

[27] South Africa, Department of Housing, Urban Development Framework, Pretoria: Government Printer, 1997. 
[28] South Africa, Department of Trade and Industry, Spatial development initiatives, 1999.

[29] Wiese, H, Regional industrial development strategies: A comparison of South African countries. Paper delivered at the EBM Research Conference. 27-28 November 1996. University of Port Elizabeth, 1996.

[30] Drewes, J.E. and Kleynhans, Re-evaluation of the Platinum SDI: a critical commentary, Town and Regional Planning, 53, pp. 1-9, 2008.

[31] South Africa, The Presidency, Integrated Sustainable Rural Development Strategy, 2000.

[32] South Africa, The Presidency, National Spatial Development Perspective, Government Printer: Pretoria, 2003.

[33] South Africa, The Presidency, National Spatial Development Perspective, Pretoria, 2006.

[34] Hughes, S, The role of intergovernmental harmonization as a national policy response to promote sustainable service delivery and development in South Africa, Unpublished paper, 2005.

[35] South Africa, Economic Development Department, New Growth Path, 2010.

[36] South Africa, The Presidency, Draft National Development Plan, 2012. 